Int. J. Dev. Biol. 51: 715-721 (2007)

doi: $10.1387 /$ ijdb.072393hl

Original Article

\title{
Coexpression of Notch3 and Rgs5 in the pericyte-vascular smooth muscle cell axis in response to pulp injury
}

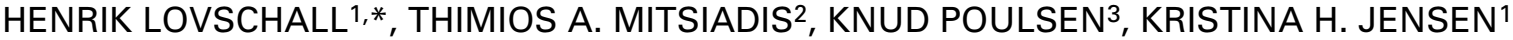 \\ and ANNETTE L. KJELDSEN ${ }^{1}$
}

\begin{abstract}
${ }^{1}$ Department of Dental Pathology, Operative Dentistry and Endodontics, Royal Dental College, Faculty of Health Sciences, University of Aarhus, Denmark, ${ }^{2}$ Department of Orofacial Development and Structure, Institute for Oral Biology, ZZMK, Faculty of Medicine, University of Zurich, Switzerland and ${ }^{3}$ Department of Medical Microbiology and Immunology, Faculty of Health Sciences, University of Aarhus,
\end{abstract} Denmark.

\begin{abstract}
Recent studies have shown that the pulp of human teeth contains a population of cells with stem cell properties and it has been suggested that these cells originate from pericytes. Molecules of the Notch signaling pathway regulate stem cell fate specification, while Rgs5 represents an excellent marker for pericytes. Pathological conditions such as dental trauma and carious lesion stimulate pulp stem cells to elaborate reparative dentin. Previous studies have shown that genes involved in the Notch pathway are activated in response to pulp injury in rodent and humans. To demonstrate the importance of pericytes as a source of stem cells during dental repair, we have studied Rgs5 and Notch 3 mRNA expression by in situ hybridization in developing, adult intact and injured rodent teeth. Furthermore, we have examined the distribution of Notch3 protein in carious and injured human teeth using immunohistochemistry. Overlapping expression patterns of Rgs5 and Notch3 were observed during rodent tooth development as well as immediately after injury. Both genes were expressed in vascular structures during development and in perivascular and single capillary cells of injured teeth. However, the expression patterns of Rgs5 and Notch3 were different during tooth repair, with relatively extensive Rgs5 expression along the pericyte-vascular smooth muscle cell axis in central pulp arterioles. These results show co-expression of Rgs5 and Notch 3 in pericytes of developing and injured teeth and furthermore indicate the importance of vascular-derived stem cells during pulp healing.
\end{abstract}

KEY WORDS: pulp injury, stem cell, tooth, wound healing, vasculature, Notch signaling

\section{Introduction}

Dental injury leads to the initiation of pulp repair through the activation of genes that are involved in stem cell fate determination (Mitsiadis et al., 1999; Lovschall et al., 2005). Formation of tissue patterns during development is somehow reiterated during regeneration of an injured tissue (Thesleff and Tummers, 2003; Martin and Parkhurst, 2004; Mitsiadis and Rahiotis, 2004). Pathological conditions, such as dental injuries and carious lesions, are often lethal to odontoblasts, which are then replaced by new cells that produce a reparative matrix called osteodentin (Fitzgerald et al., 1990). Adult pulp stem cells are the reservoir of reparative cells after dental injury. They proliferate and migrate to the wounded site, where, in cooperation with local cells, participate in tooth repair (Løvschall et al., 2007). Stem cells isolated from the dental pulp are capable of forming osteodentin in vitro and ex vivo
(Shi and Gronthos, 2003; lohara et al., 2006) and they have been suggested to originate from pericytes (Shi and Gronthos, 2003).

Pericytes are enclosed in the basement membrane of blood vessels and surround endothelial cells. The pericyte coverage of the endothelium is partial depending on the vascular bed (Shepro and Morel, 1993; Rucker et al., 2000). There appears to exist a continuum of phenotypes ranging from the classical vascular smooth muscle cell (VSMC) to the typical pericyte distributed subjacent to the endothelium (Andreeva et al., 1998). Pericytes modulate their phenotype along this pericyte-vSMC axis and several findings suggest they may transdifferentiate into other cell types, including osteoblasts, chondroblasts, fibroblasts, adipocytes (Nehls and Drenckhahn, 1993) and odontoblasts (Alliot-Licht et al., 2001; Shi and Gronthos, 2003).

Abbreviations used in this paper: vSMC, vascular smooth muscle cell.

\footnotetext{
*Address correspondence to: Henrik Lovschall. Department of Dental Pathology, Operative Dentistry and Endodontics, Royal Dental College, Vennelyst Boulevard 9, University of Aarhus, DK-8000 Aarhus C, Denmark. Fax: +45-8620-2202. e-mail: loev@odont.au.dk
} 
Fig. 1. Expression patterns of Notch 3 and Rgs5 in developing post-natal mouse teeth. (A-H) Radioactive in situ hybridization on sections of developing mandibular mice molars and incisors at post-natal day two. (A,C-E) Microphotographs of grains from dark-field superimposed in red color on brightfield (hematoxilin stain). (B,F) Grains in yellow color superimposed on fluorecence-field (Hoechst stain). (G,H) Grains in bright-field with black grains on hematoxilin stained background. $(\mathbf{A}, \mathbf{B})$ Overview of the incisor (down/right) and the first molar (up/left). Notch3 (A) and Rgs5 (B) hybridization signal in central arterioles (arrows) and peripheral capillaries near the odontoblastic layer (arrowheads). (C) Notch3 expression across the pulp horn (arrows) in developing molar (magnification of boxed area in A) and in pericytes along the blood vessels (arrowheads) that invade the stellate reticulum (sr). (D) Rgs 5 expression in the stellate reticulum and pulp (arrowheads) in the developing molar. (E) Magnification of boxed area in (D) showing Rgs5 expression in pericyte-like locations (arrowheads) along blood vessels invading the mouse molar stel-
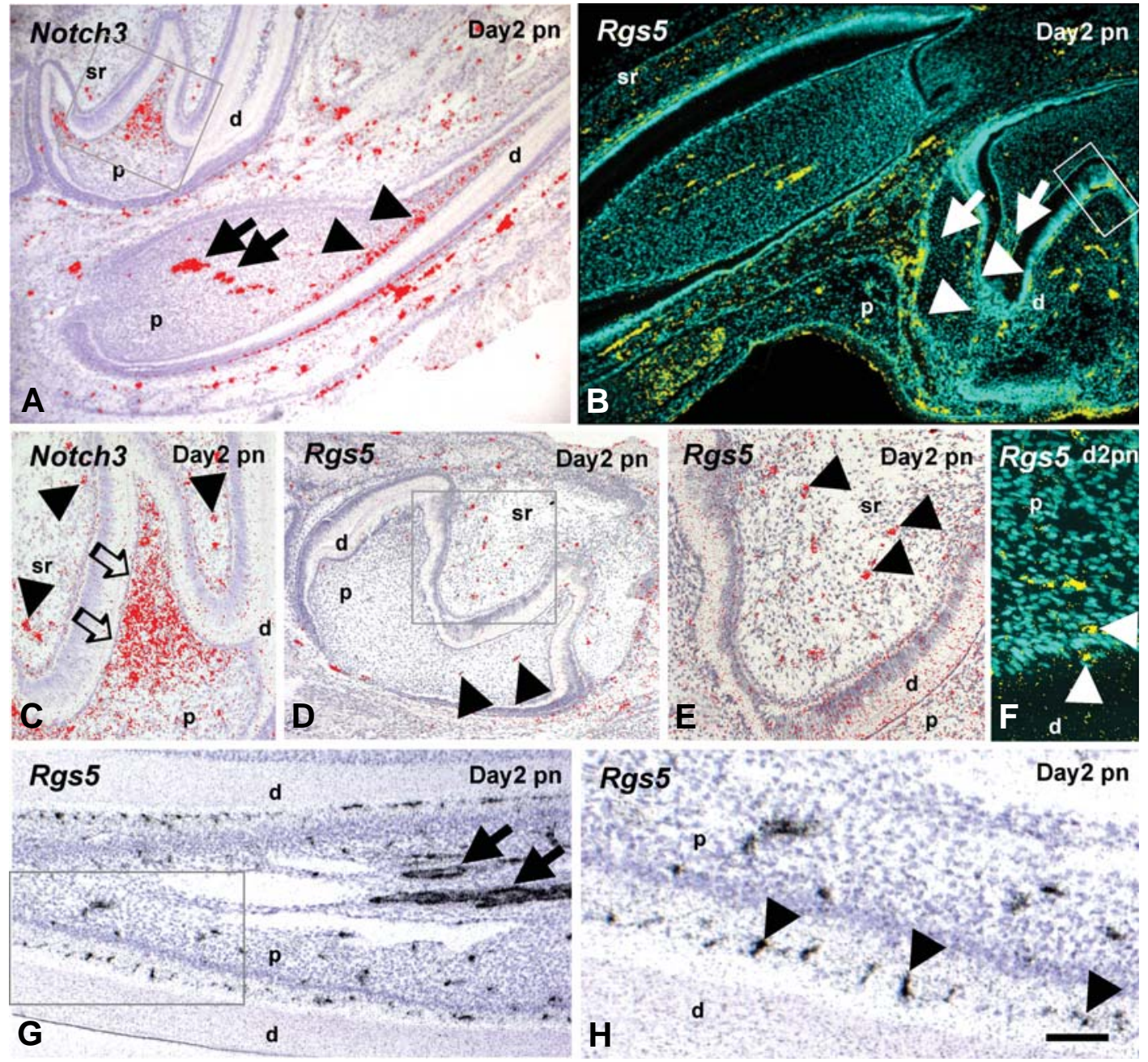

late reticulum after birth. (F)

Magnification of boxed area in (B), showing the Rgs5 hybridization signal (arrowheads) along peripheral juxtaodontoblastic capillaries. (G,H) Rgs 5 expression in the mural cells along central arterioles (arrows in G) and in cells along the juxtaodontoblastic capillary tree (arrowheads in H). (H) is a magnification of the boxed area in (G). Abbreviations: $p$, pulp; d, dentin; sr, stellate reticulum. The bar in (H) represents in A, B,D: $200 \mu \mathrm{m}, C: 80 \mu \mathrm{m}$, E: $100 \mu \mathrm{m}, \mathrm{F}, \mathrm{H}: 50 \mu \mathrm{m}, \mathrm{G}: 125 \mu \mathrm{m}$.

Pericyte markers include proteins such as smooth muscle $\alpha$ actin (SMA), NG2, PDGFR-beta, RGS5 (Armulik et al., 2005) and $3 G 5$ (Shi and Gronthos, 2003). However, the expression patterns of these molecules are tissue and time dependent. None of these markers are absolutely specific for pericytes and none recognizes all pericytes (Armulik et al., 2005). Rgs5 is the earliest gene which is activated in pericytes during neovascularization (Bondjers et al., 2003). RGS5 protein stimulates GTPase activity, which accelerates G-protein inactivation and thereby inhibits signaling downstream of G-protein-coupled receptors (Anger et al., 2004).

The Notch signaling pathway regulates the fate of stem cells in most tissues and organs (Gray et al., 1999). Notch signaling operates through local cell-cell interactions and is involved in a wide range of developmental processes including odontogenesis (Mitsiadis et al., 1995; 1997; 1998; 2005; Harada et al., 1999; Tummers and Thesleff, 2003), vasculogenesis (Iso et al., 2003), hematopoiesis (Kojika and Griffin, 2001) and formation of skin appendages (Thelu et al., 2002). Notch signaling is reactivated during repair of injured tissues and organs (Mitsiadis et al., 1999; 2003; Lindner et al., 2001; Thelu et al., 2002; Lovschall et al., 2005). Studies on pulp-dentin repair after perforation of adult rat molars have shown activation of the Notch signaling pathway in teeth with both open perforations (Mitsiadis et al., 1999) and pulp capping (Lovschall et al., 2005). These studies have demonstrated that Notch3 expression is mainly associated with perivascular cells, Notch1 expression is restricted to pulp cells close to the lesion, whereas Notch2 in the pulp is expressed much more widely (Mitsiadis et al., 1999; 2003; Lovschall et al., 2005).

Studies on vascular markers potentially involved in determination of pericyte and stem cell fates have become increasingly relevant. The aim of the present study was to demonstrate the importance of pericytes as a source of stem cells during dental repair. For this purpose we have studied Notch3 and Rgs5 expression in developing, adult healthy and injured rodent teeth and furthermore Notch 3 protein expression in response to carious and traumatic pulp-dentin injury in human teeth both in vitro and in vivo. 


\section{Results}

\section{Rgs5 and Notch3 expression in developing mouse teeth}

Hybridization signals using radiolabeled antisense riboprobes were detected for both Rgs5 and Notch3 genes on histological sections from developing post-natal mouse tooth germs. In the post-natal day 2 molars, Notch 3 and Rgs 5 transcripts were detected in pericytes of vascular structures of the dental pulp, as well as in the stellate reticulum where blood vessels enter after birth (Fig. 1A-E). A strong hybridization signal for Notch3 was also localized across the pulp horns. In the incisor pulp, the Rgs5 and Notch3£hybridization signals were found along the inner deep plexus of arterioles and the outer capillary tree (Fig.1A,B,F,G,H).

\section{Rgs5 and Notch3 expression after injury in rat teeth}

The hybridization signals for Rgs5 and Notch3 were upregulated in blood vessel-related structures after pulp injury in adult rat molars (Fig. 2B,C,E,F,H-K,N and Fig. 3) when compared to the intact molars (Fig. 2D,G). The hybridization signals for Rgs5 and Notch3 were observed in perivascular locations near and at a distance from the injury site. Rgs5 and Notch3 hybridization signals were observed in single cells juxtaposing endothelial cells that correspond to capillary and arteriolar pericytes. Notch3 expression was up-regulated in vascular structures the first days after the dental lesion (Fig. 2E,F,H-J), but expression decreased in following weeks after surgery (Fig. 3C,E). By contrast, vascular Rgs5 expression was more extended and maintained in the weeks post-injury (Fig. 3A,B,D,F). Rgs5 expression was more extensive along the pericyte-vascular smooth muscle cell axis in the central pulp arterioles when compared with Notch3 expression. Control sections from intact adult molars showed weaker hybridization signals and minor perivascular expression (Fig. 2D,G). The hybridization signals were almost absent in sections using sense Notch3 and Rgs5 RNA riboprobes (not shown).
Fig. 2. Expression patterns of Notch3 and Rgs5 in injured rat teeth one and three days postsurgery. (A) Schematic representation of a first adult rat molar after experimental perforation at the mesial cusp. Arrows indicate the regions of interest. The pulp horn was capped after perforation by Dycal and IRM. The mesial side is presented to the left on photomicrographs (B-I \& L-N). (B-N) Radioactive in situ hybridization on sections of intact rat molars (D, G), injured rat molars at post-operation day one (B,C, E,F) and post-operation day three $\mathbf{( H -}$ N). Grains, establishing cell specific hybridization signal, are superimposed as dark-field microphotographs of original white grains in $(\mathbf{E}, \mathbf{F})$, as yellow color in (B,C) and as red/orange color in $\mathbf{( D , G} \& \mathbf{H}$ K) on fluorescence field (Hoechst stain). Black grains on bright-field microphotographs (hematoxylin stain) are seen in (N). (B,C,E,F) Central part of the mesial root canal. The direction of injury is indicated by small arrows. Endothelial cells in F are indicated with open white arrows, hybridization signal in pericytes with white arrows. (B,C) Rgs5 hybridization signals (yellow color) are evident in pericytes around central arterioles (a). (E,F) Notch3 is also expressed in pericytes (white color) around central arterioles (outlined with a red line in E). Boxed areas in $(B, E)$ represent magnifications in $(C, F)$ respectively. (D,G) Rgs5 and Notch3 expression (white arrows) in intact molars. $(\mathbf{H}, \mathbf{I})$ Central and upper part of the mesial root canal including the injury and necrotic (n) areas. Notch3 expression in pericytes (white arrows) around the central arteriole (a) in close contact with endothelial cells lopen white arrow). Notch3 is also expressed in single cells along juxta-odontoblastic capillaries (arrowheads).
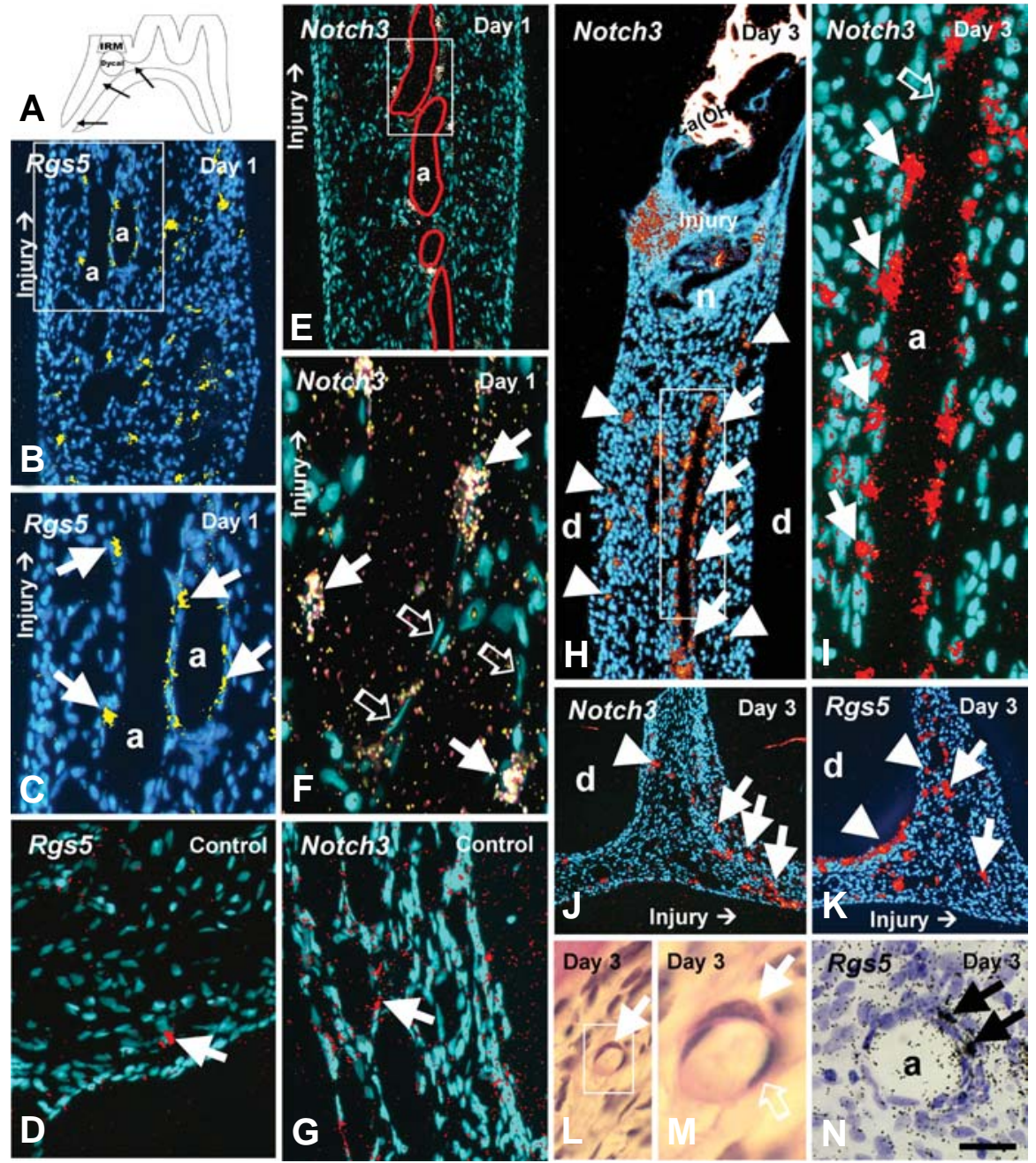

Boxed area in (H) represents magnification in (I). (J,K) Central coronal pulp, the injury (small arrows) to the right. Similar expression patterns for Notch3 in (J) and Rgs5 in (K) are detected in pericytes (white arrows) around arterioles and in cells along juxta-odontoblastic capillaries (arrowheads). (L,M) Coronal pulp area (PAS stain). Boxed area in (L) represents magnification in (M), where endothelial cells (open white arrow) are in part covered by pericyte (white arrow). (N) Rgs5 expression in pericytes (black arrows) around a coronal arteriole (a) (hematoxylin stain). Abbreviations: a, arteriole; d, dentin; n, necrotic pulp area. The bar in (N) represents in (B,E): $100 \mu \mathrm{m}, \mathrm{C}, \mathrm{D}, \mathrm{G}, \mathrm{L}: 50 \mu \mathrm{m}, \mathrm{F}: 20 \mu \mathrm{m}, \mathrm{H:} 120 \mu \mathrm{m}, \mathrm{I,N}: 40 \mu \mathrm{m}, \mathrm{J}, \mathrm{K}: 200 \mu \mathrm{m}, \mathrm{M}: 15 \mu \mathrm{m}$ 

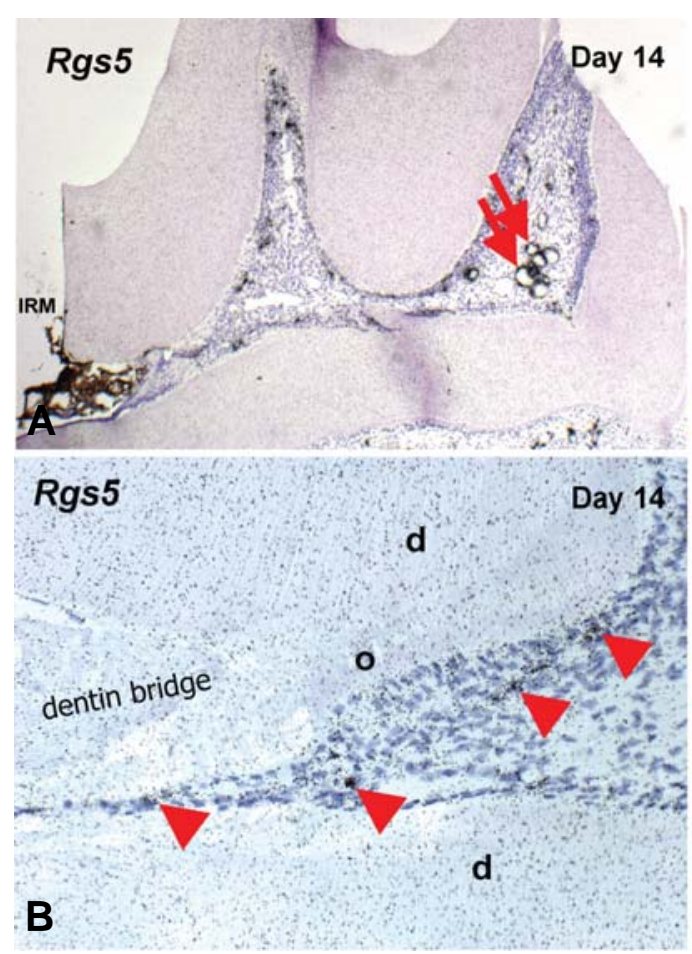
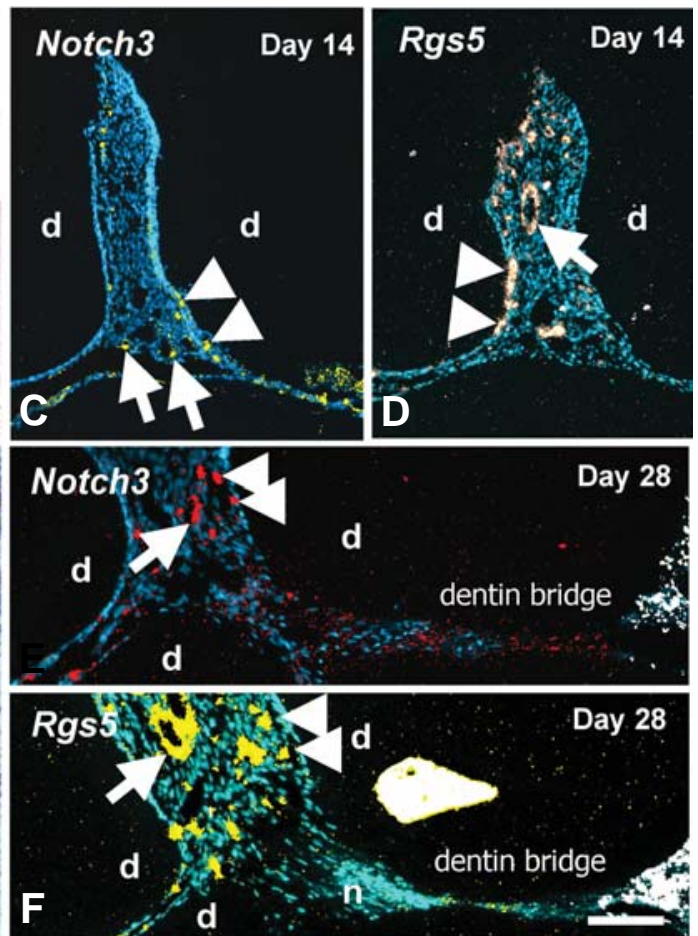

\begin{abstract}
d
\end{abstract}

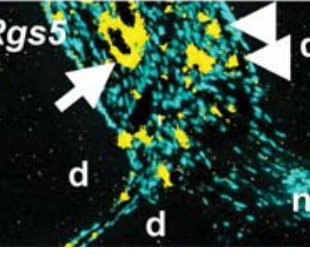

\section{D}

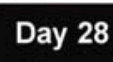

d
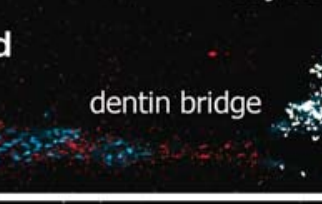

Day 28

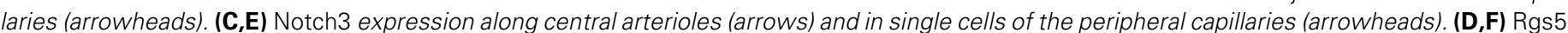

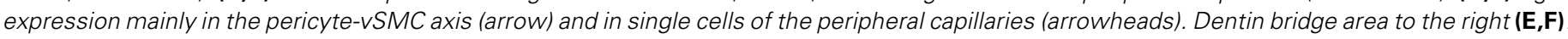
Abbreviations: $d$, dentin; $n$, necrotic pulp area; o, odontoblasts. The bar in (F) represents in (A,C,D): $150 \mu m, B: 75 \mu m$; $E, F: 100 \mu m$.

\section{Notch3 protein expression in injured, carious and cultured human teeth}

Immunohistochemistry, by using an antibody that recognizes the intracellular domain of the Notch3 protein, showed a similar expression pattern of the Notch3 protein in vascular structures of pathological human teeth. In injured teeth, nine weeks after cavity preparation ('drilling'), as well as in teeth with advanced carious lesions, the Notch3 immunostaining was observed in the walls of dilated blood vessels (Fig. 4A-D). Staining was also detected in isolated pulp cells of carious teeth (Fig. 4D). In cultured human tooth slices, Notch3 staining was intense in cells of the putatively new-formed vessels (red arrows; Fig. 4E,G). Notch3 protein was also detected in odontoblasts of cultured tooth slices (green arrows; Fig. 4E,F).

\section{Discussion}

The present study demonstrates that expression of Notch3 and Rgs5 is activated in response to dental injury. Notch3 and Rgs5 were strongly expressed in the pericyte-vSMC axis of the vascular wall both in the developing and in adult injured teeth. Notch3 expression was highly activated as an early response to pulp injury and expression decreased with time during pulp healing. Notch3 was expressed in single cells of vessels juxtaposing endothelial cells that correspond to capillary and arteriolar pericytes, which are localized either close to or inside the odontoblast layer (Josephsen et al., 1974). These results are in agreement with recent findings demonstrating a similar expression pattern of Notch3 expression in pericytes of the retina (Claxton and Fruttiger, 2004). Activation of Notch3 expression during tooth repair might be important for the regulation of the fate of pericyte-derived stem cells. It has been shown that the Notch signaling pathway is essential for stem cell fate regulation and appropriate differentiation of many cell types during development (Lewis, 1998).

Notch receptors and ligands are involved in a variety of pathological conditions (Gridley, 2003), including dental pathology in humans (Mitsiadis et al., 2003) and rodents (Mitsiadis et al., 1999; Lovschall et al., 2005). In injured teeth, two of the Notch ligands, Delta1 and Jagged1, are expressed in small groups of vascular and perivascular cells (Mitsiadis et al., 1999; Lovschall et al., 2005). The present findings are in agreement with the concept that activation of the Notch signaling pathway plays a central role during tooth repair and neovascularization. Both Notch3 transcripts and protein were upregulated in vascular structures of the injured and carious teeth. However, in cultured human tooth slices Notch3 protein was also upregulated in odontoblastic cells. Potentially, these cells are not able anymore to maintain the odontoblastic fate and they start to dedifferentiate, adopting thus another fate, or die. Another possible explanation is that the Notch3 protein is expressed in pericytes, loses its extracellular domain by proteolysis in response to the injury and retains the intracellular domain in cells that finally differentiate into odontoblasts. The upregulation of Notch3 in vascular structures during pathological conditions suggests that signaling through the Notch3 receptor play a pivotal role in the control of vascularderived cell fates. A similar role could be suggested for Notch3 during tooth development, where the present and previous studies have showed that Notch 3 expression is mostly correlated with cells located in the walls of blood vessels in continuously erupting 

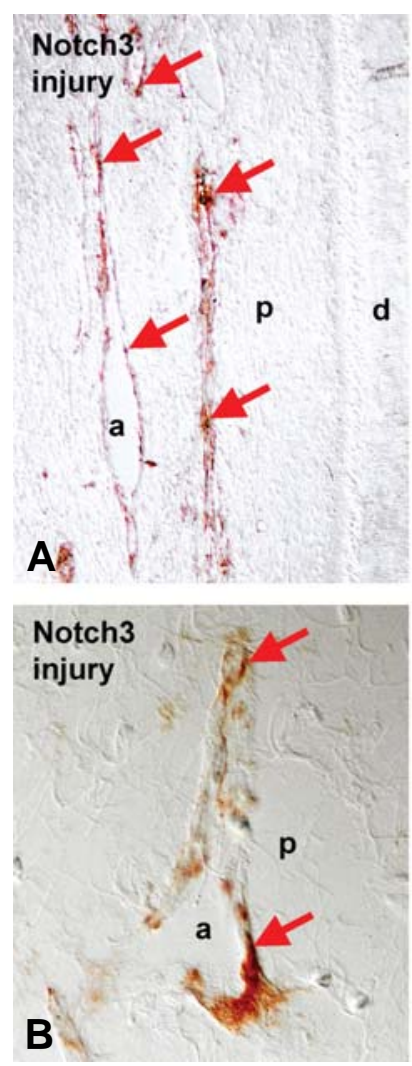
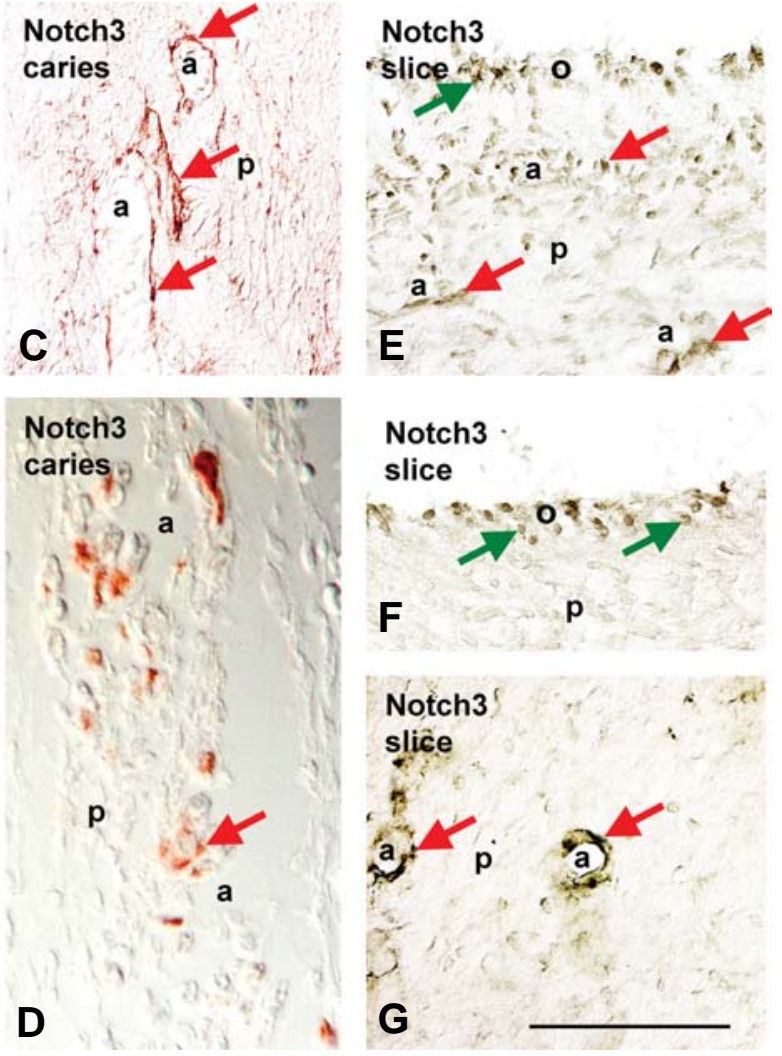

Fig. 4. Distribution of the Notch3 protein in injured, carious and cultured human teeth. Immunodetection of the intracellular Notch3 domain in injured (A,B), carious (C,D) and cultured (E-G) human teeth. (A,D) Notch3-positive cells (red color) around the arterioles (a, arrows). Staining is also observed sporadically in pulp cells. (E-G) In cultured slices of intact human teeth, Notch3 protein is observed in odontoblasts (green arrows in E,F) and in putatively new-formed arterioles (a) (red arrows in E, G). Abbreviations: a, arteriole; d, dentin; o, odontoblasts; $p$, dental pulp. The bar in (G) represents in $(A, C): 50 \mu m, B, D, E, F, G: 30 \mu \mathrm{m}$.

mouse incisors and vole molars (Tummers and Thesleff, 2003).

In developing and injured teeth, Rgs5 was expressed in capillary walls and in single cells around central arterioles, which often were observed juxtaposing endothelial cells. The Rgs5 expression extended from pericytes to the vascular smooth muscle cells in the tunica media. Pericytes may change their phenotype along the pericyte-vSMC axis (Nehls and Drenckhahn, 1993; Andreeva et al., 1998). Previous reports have suggested RGS5 as a marker for pericytes (Bondjers et al., 2003; Cho et al., 2003), vSMCs (Li et al., 2004) and activated pericytes during wound healing and vascular remodeling (Berger et al., 2005). The present results show that Rgs5 and Notch3 are co-expressed in the pericytes and along the $v S M C$ axis. RGS proteins are regulators of the G-protein and have been implicated in the control of chondroblast (Appleton et al., 2006) and osteoblast (Thirunavukkarasu et al., 2002) differentiation, as well as in the differentiation of mural cells during embryonic vascular maturation (Cho et al., 2003) and peripheral artery function (Li et al., 2004). Notch3 is crucial for tissue homeostasis since mutation of this gene leads to CADASIL, a systemic disease in the arterioles (Brulin et al., 2002). Recent findings have shown that Notch3 is involved in the specification and control of arterial identity during angiogenesis (Claxton and Fruttiger, 2004; Armulik et al., 2005).

The present results suggest that Notch3 is also involved in cell fate regulation during dental pulp remodeling. It has been suggested recently that residual Rgs5 expression may be present in sporadic and rare pericytes, which might adopt a non-vascular cell fate (Bondjers et al., 2003). During pulp repair, Notch3 and Rgs5 expression in the healing pulp is correlated with sporadic cells of the vascular structures, but not with proliferating and migrating new cells that border the injury interface during repair (Feit et al., 1970; Fitzgerald, 1979; Dahl, 1983; Fitzgerald et al., 1990). Notch3 and Rgs5 were frequently expressed in single cells distributed along this vascular tree. Up-regulation of Notch 3 and Rgs 5 expression in pericytes is seen around vessels near and distant from the injury site, including new invading vessels, as well as during tooth repair with increased expression around vessels close to the injury site. In few cases Notch3 and Rgs5expression was down-regulated around the wounded area, indicating that tooth perforation and pulp capping may occasionally occlude and impair the adjoining microvascular system. Notch3 and Rgs5 hybridization signals were not expressed in cells that border the injury interface during repair and prior to neovascularization.

Dental injury stimulates recruitment of cells that differentiate into odontoblast-like cells and possess a reparative capacity (Fitzgerald et al., 1990). The environment in the granulation tissue and proliferation phase of pulp healing provides a niche, which allows for generation of odontogenic progeny from the stem cells. Recent studies based on in vitro isolation and transplantation of STRO-1 positive pulp cells have suggested that pericytes may be odontogenic precursors (Gronthos et al., 2004). Our studies indicate that Notch3 and Rgs5 expression are involved in regulation of the fate of pericytes or recruitment of new cells during angiogenesis and neovascularization. Dental injury is expected to provide networks of complex epigenetic signals (Mitsiadis and Rahiotis, 2004; Løvschall et al., 2007), including cascades of cytokines, redistribution of extracellular matrix molecules and growth factors (Silva et al., 2004) and putative homotypic or heterotypic cell-to-cell interactions (Thesleff et al., 1996; Mitsiadis and Rahiotis, 2004), which may influence the fate of vascularderived dental stem cells.

\section{Materials and Methods}

\section{Animal experiments}

Experiments were approved by the Danish Experimental Animal Board. Teeth of two-months old male Wistar rats (Møllegaarden, Eiby, Denmark) were disinfected and mesio-buccal pulp horn in first upper molars were perforated as previously described (Lovschall et al., 2001). Pulp capping was made using hard setting calcium hydroxide (Dycal Cement, LD Chaulk Company, Del, USA). Cavities were filled with IRM- 
cement (Dentsply, DeTrey, Germany) (Figure 2A).

\section{Processing of tissues}

For in situ hybridization analysis, experimental and control rats were anaesthetized and sacrificed 1, 3, 7, 14 or 28 days after pulp treatment by vascular perfusion fixation with pre-rinsing in saline. For perfusion fixation, $4 \%$ paraformaldehyde (PFA) in PBS at $4^{\circ} \mathrm{C}$ was used for $10 \mathrm{~min}$, followed by over-night immersion fixation of the rat molars and incisors (Lovschall et al., 2002). Developing teeth from postnatal mice were immersed in the same fixative. All specimens were decalcified in 12.5\% EDTA (ethylenediamine tetraacetic acid) containing 2.5\% PFA for 4-6 weeks, dehydrated, embedded in paraffin and serially sectioned at $6 \mu \mathrm{m}$ (Lovschall et al., 2005). Hoechst 33342, hematoxylin, or PAS was used as background stain.

\section{Probes and in situ hybridization}

In situ hybridization on paraffin sections was performed as described previously (Vainio et al., 1993). The Rgs5 and Notch3 plasmids that were used for making the ${ }^{35} \mathrm{~S}$-UTP-labeled riboprobes were kind gifts from $\mathrm{Dr}$ Christer Betsholtz (Karolinska Institute, Sweden) (Cho et al., 2003; Bondjers et al., 2003) and Prof. Urban Lendahl (Karolinska Institute, Sweden) (Larsson et al., 1994) respectively. The plasmids were transformed into Escherichia coli TOP10 (Invitrogen) and plasmid DNA was purified using the Plasmid Maxi Kit (Qiagen). For preparing the antisense and sense (for control experiments) riboprobes the plasmid DNA was linearized by cleaving with restriction enzymes prior to labelling with [35S]-UTP by using T3 or T7 polymerase. Fluorescence-, dark-, or bright-field microscopical fields were photographed digitally to capture the full dynamic range of image without exceeding the capacity of the camera (Axiocam MRc5) in similar locations of section. Grains from the dark-field were selected, colored and added to the bright-field pictures in Photoshop CS.

\section{Permanent intact, carious and injured human teeth}

The human teeth used in this study were mature, intact, carious, or injured teeth. Cavity preparation in intact first premolars scheduled for extraction was performed as previously described (Heymann et al., 2002). The cavities were restored with IRM. After a post-operative interval of 9 weeks, the teeth were extracted with the patient's informed consent. Teeth were fixed in $10 \%$ neutral-buffered formalin for 24 hours, demineralized in sodium formiate for 3 weeks and then embedded in paraffin wax. Teeth were serially sectioned ( $6 \mu \mathrm{m}$ thick sections) and then processed for immunohistochemistry.

\section{Culture of human dental slices}

Human premolars and molars extracted for orthodontic reasons were cut into $750 \mu \mathrm{m}$ slices. These slices were cultured as previously described (Mitsiadis et al., 2003).

\section{Antibodies and immunohistochemistry}

Rabbit antiserum against the intracellular domain of the mouse Notch3 protein (Mitsiadis et al., 1999) were used. Vector Vectastain ABC kit with a biotinylated secondary antibody and peroxidase-conjugated avidin was purchased from Biosys (Compiègne, France). Immunohistochemistry on paraffin sections was performed as previously described (Mitsiadis et al., 2003).

\section{Acknowledgments}

We wish to thank P. Kjærgaard deeply for skillful technical assistance. This investigation was supported by the European COST B23 Action and grants from the Aarhus University Research Foundation, University of Zurich and the Danish Dental Association.

\section{References}

ALLIOT-LICHT, B., HURTREL, D. and GREGOIRE, M. (2001) Characterization of alpha-smooth muscle actin positive cells in mineralized human dental pulp cultures. Arch Oral Biol 46: 221-228.

ANDREEVA, E. R., PUGACH, I. M., GORDON, D. and OREKHOV, A. N. (1998) Continuous subendothelial network formed by pericyte-like cells in human vascular bed. Tissue Cell 30: 127-135.

ANGER, T., ZHANG, W. and MENDE, U. (2004) Differential contribution of GTPase activation and effector antagonism to the inhibitory effect of RGS proteins on Gqmediated signaling in vivo. $J$ Biol Chem 279: 3906-3915.

APPLETON, C. T., JAMES, C. G. and BEIER, F. (2006) Regulator of G-protein signaling (RGS) proteins differentially control chondrocyte differentiation. J Cell Physiol 207: 735-745.

ARMULIK, A., ABRAMSSON, A. and BETSHOLTZ, C. (2005) Endothelial/pericyte interactions. Circ Res 97: 512-523.

BERGER, M., BERGERS, G., ARNOLD, B., HAMMERLING, G. J. and GANSS, R. (2005) Regulator of G-protein signaling-5 induction in pericytes coincides with active vessel remodeling during neovascularization. Blood 105: 1094-1101.

BONDJERS, C., KALEN, M., HELLSTROM, M., SCHEIDL, S. J., ABRAMSSON, A., RENNER, O., LINDAHL, P., CHO, H., KEHRL, J. and BETSHOLTZ, C. (2003) Transcription profiling of platelet-derived growth factor-B-deficient mouse embryos identifies RGS5 as a novel marker for pericytes and vascular smooth muscle cells. Am J Pathol 162: 721-729.

BRULIN, P., GODFRAIND, C., LETEURTRE, E. and RUCHOUX, M. M. (2002) Morphometric analysis of ultrastructural vascular changes in CADASIL: analysis of 50 skin biopsy specimens and pathogenic implications. Acta Neuropathol (Berl) 104: 241-248.

CHO, H., KOZASA, T., BONDJERS, C., BETSHOLTZ, C. and KEHRL, J. H. (2003) Pericyte-specific expression of Rgs5: implications for PDGF and EDG receptor signaling during vascular maturation. FASEB J 17: 440-442.

CLAXTON, S. and FRUTTIGER, M. (2004) Periodic Delta-like 4 expression in developing retinal arteries. Gene Expr Patterns 5: 123-127.

DAHL, J. E. (1983) Proliferation and migration of rat incisor mesenchymal cells. Scand $J$ Dent Res 91: 335-340.

FEIT, J., METELOVA, M. and SINDELKA, Z. (1970) Incorporation of $3 \mathrm{H}$ thymidine into damaged pulp of rat incisors. J Dent Res 49: 783-786.

FITZGERALD, M. (1979) Cellular mechanics of dentinal bridge repair using $3 \mathrm{H}-$ thymidine. J Dent Res 58: 2198-2206.

FITZGERALD, M., CHIEGO, D. J., JR. and HEYS, D. R. (1990) Autoradiographic analysis of odontoblast replacement following pulp exposure in primate teeth. Arch Oral Biol 35: 707-715.

GRAY, G. E., MANN, R. S., MITSIADIS, E., HENRIQUE, D., CARCANGIU, M. L., BANKS, A., LEIMAN, J., WARD, D., ISH, H. D. and ARTAVANIS, T. S. (1999) Human ligands of the Notch receptor. Am J Pathol 154: 785-794.

GRIDLEY, T. (2003) Notch signaling and inherited disease syndromes. Hum Mol Genet 12: R9-R13.

GRONTHOS, S., CHERMAN, N., ROBEY, P. G. and SHI, S. (2004) Human Dental Pulp Stem Cells - Characterization and Developmental Potential. In Adult Stem Cells M. TURKUN, ed., pp. 67-81, Humana Press, Totowa, New Jersey.

HARADA, H., KETTUNEN, P., JUNG, H. S., MUSTONEN, T., WANG, Y. A. and THESLEFF, I. (1999) Localization of putative stem cells in dental epithelium and their association with Notch and FGF signaling. J Cell Biol 147: 105-120.

HEYMANN R., ABOUTI., LENDAHL U., FRANQUIN J.C., OBRINK B. and MITSIADIS T.A. (2002). E- and $\mathrm{N}$-cadherin distribution in developing and functional human teeth under normal and pathological conditions. Am J Pathol. 160:2123-2133.

IOHARA K., ZHENG L., ITO M., TOMOKIYO A., MATSUSHITA K. and NAKASHIMA M. (2006). Side population cells isolated from porcine dental pulp tissue with selfrenewal and multipotency for dentinogenesis, chondrogenesis, adipogenesis and neurogenesis. Stem Cells. 24:2493-503.

ISO, T., HAMAMORI, Y. and KEDES, L. (2003) Notch signaling in vascular development. Arterioscler Thromb Vasc Biol 23: 543-553.

JOSEPHSEN, K., FEJERSKOV, O. and THEILADE, J. (1974) Age changes in juxtaodontoblastic capillaries of rat molars. Scand J Dent Res 82: 574-578.

KOJIKA, S. and GRIFFIN, J. D. (2001) Notch receptors and hematopoiesis. Exp Hematol 29: 1041-1052.

LARSSON, C., LARDELLI, M., WHITE, I. and LENDAHL, U. (1994) The human NOTCH1, 2 and 3 genes are located at chromosome positions 9q34, 1p13-p11 and 19p13.2-p13.1 in regions of neoplasia-associated translocation. Genomics 
24: $253-258$.

LEWIS, J. (1998) Notch signalling and the control of cell fate choices in vertebrates. Semin Cell Dev Biol 9: 583-589.

LI, J., ADAMS, L. D., WANG, X., PABON, L., SCHWARTZ, S. M., SANE, D. C. and GEARY, R. L. (2004) Regulator of G protein signaling 5 marks peripheral arterial smooth muscle cells and is downregulated in atherosclerotic plaque. $J$ Vasc Surg 40: 519-528.

LINDNER, V., BOOTH, C., PRUDOVSKY, I., SMALL, D., MACIAG, T. and LIAW, L. (2001) Members of the Jagged/Notch gene families are expressed in injured arteries and regulate cell phenotype via alterations in cell matrix and cell-cell interaction. Am J Pathol 159: 875-883.

LOVSCHALL, H., FEJERSKOV, O. and FLYVBJERG, A. (2001) Pulp capping with recombinant human insulin-like growth factor I (rhIGF-I) in rat molars. Advances in Dental Research 35: 108-112.

LOVSCHALL, H., FEJERSKOV, O. and JOSEPHSEN, K. (2002) Age-related and site-specific changes of pulp histology in Wistar rat molars. Arch Oral Biol1197: 1-7.

LOVSCHALL, H., TUMMERS, M., THESLEFF, I., FUCHTBAUER, E. M. and POULSEN, K. (2005) Activation of the Notch signaling pathway in response to pulp capping of rat molars. Eur J Oral Sci 113: 312-317.

LØVSCHALL, H., GIANNOBILE, W.V., SOMERMAN, M.J., JIN, O. and ANDREASEN, J.O. (2007). Stem cells and regeneration of injured dental tissue. In: Textbook and Color Atlas of Traumatic Injuries to the Teeth. Andreasen JO, Andreasen FM, Anderson L, editors Blackwell Pub Professional.

MARTIN, P. and PARKHURST, S. M. (2004) Parallels between tissue repair and embryo morphogenesis. Development 131: 3021-3034.

MITSIADIS, T. A., FRIED, K. and GORIDIS, C. (1999) Reactivation of Delta-Notch signaling after injury: complementary expression patterns of ligand and receptor in dental pulp. Exp Cell Res 246: 312-318.

MITSIADIS, T. A., HENRIQUE, D., THESLEFF, I. and LENDAHL, U. (1997) Mouse Serrate-1 (Jagged-1): expression in the developing tooth is regulated by epithelial-mesenchymal interactions and fibroblast growth factor-4. Development 124: 1473-1483.

MITSIADIS T.A., HIRSINGER E., LENDAHL U. and GORIDIS C. (1998). Deltanotch signaling in odontogenesis: correlation with cytodifferentiation and evidence for feedback regulation. Dev Biol. 204:420-431.

MITSIADIS, T. A., LARDELLI, M., LENDAHL, U. and THESLEFF, I. (1995) Expression of Notch 1, 2 and 3 is regulated by epithelial- mesenchymal interactions and retinoic acid in the developing mouse tooth and associated with determination of ameloblast cell fate. J Cell Biol 130: 407-418.

MITSIADIS T.A. and RAHIOTIS C. (2004). Parallels between tooth development and repair: conserved molecular mechanisms following carious and dental injury. J Dent Res. 83:896-902.

MITSIADIS T.A., REGAUDIAT L. and GRIDLEY T. (2005). Role of the Notch signalling pathway in tooth morphogenesis. Arch Oral Biol. 50:137-140.

MITSIADIS, T. A., ROMEAS, A., LENDAHL, U., SHARPE, P. T. and FARGES, J. C. (2003) Notch2 protein distribution in human teeth under normal and pathological conditions. Exp Cell Res 282: 101-109.

NEHLS, V. and DRENCKHAHN, D. (1993) The versatility of microvascular pericytes: from mesenchyme to smooth muscle? Histochemistry 99: 1-12.

RUCKER, H. K., WYNDER, H. J. and THOMAS, W. E. (2000) Cellular mechanisms of CNS pericytes. Brain Res Bull 51: 363-369.

SHEPRO, D. and MOREL, N. M. (1993) Pericyte physiology. FASEB J 7: 10311038.

SHI, S. and GRONTHOS, S. (2003) Perivascular niche of postnatal mesenchymal stem cells in human bone marrow and dental pulp. J Bone Miner Res 18: 696704.

SILVA, T. A., ROSA, A. L. and LARA, V. S. (2004) Dentin matrix proteins and soluble factors: intrinsic regulatory signals for healing and resorption of dental and periodontal tissues? Oral Dis 10: 63-74.

THELU, J., ROSSIO, P. and FAVIER, B. (2002) Notch signalling is linked to epidermal cell differentiation level in basal cell carcinoma, psoriasis and wound healing. BMC Dermatol 2: 7.

THESLEFF, I. and TUMMERS, M. (2003) Stem cells and tissue engineering: prospects for regenerating tissues in dental practice. Med Princ Pract 12 Suppl 1: 43-50.

THESLEFF, I., VAAHTOKARI, A., VAINIO, S. and JOWETT, A. (1996) Molecular mechanisms of cell and tissue interactions during early tooth development. Anat Rec 245: 151-161.

THIRUNAVUKKARASU, K., HALLADAY, D. L., MILES, R. R., GERINGER, C. D. and ONYIA, J. E. (2002) Analysis of regulator of G-protein signaling-2 (RGS-2) expression and function in osteoblastic cells. J Cell Biochem 85: 837-850.

TUMMERS, M. and THESLEFF, I. (2003) Root or crown: a developmental choice orchestrated by the differential regulation of the epithelial stem cell niche in the tooth of two rodent species. Development 130: 1049-1057.

VAINIO, S., KARAVANOVA, I., JOWETT, A. and THESLEFF, I. (1993) Identification of BMP-4 as a signal mediating secondary induction between epithelial and mesenchymal tissues during early tooth development. Cell 75: 45-58.

Published Online: 6th September 2007 


\section{Related, previously published Int. J. Dev. Biol. articles}

See our Special Issue Tooth Development edited by Jean Victor Ruch http://www.ijdb.ehu.es/web/contents. php?vol=39\&issue=1

Amniotic fluid induces rapid epithelialization in the experimentally ruptured fetal mouse palate - implications for fetal wound healing Toshiya Takigawa and Kohei Shiota Int. J. Dev. Biol. (2007) 51: 67-77

Formation of a successional dental lamina in the zebrafish ( Danio rerio ): support for a local control of replacement tooth initiation

Ann Huysseune

Int. J. Dev. Biol. (2006) 50: 637-643

Notch in vertebrates - molecular aspects of the signal

Ken-Ichi Katsube and Kei Sakamoto

Int. J. Dev. Biol. (2005) 49: 369-374

Role of Jun N-terminal Kinase (JNK) signaling in the wound healing and regeneration of a Drosophila melanogaster wing imaginal disc

Jaakko Mattila, Leonid Omelyanchuk, Satu Kyttälä, Heikki Turunen and Seppo Nokkala Int. J. Dev. Biol. (2005) 49: 391-399

Activin-like signaling activates Notch signaling during mesodermal induction

Takanori Abe, Miho Furue, Yasufumi Myoishi, Tetsuji Okamoto, Akiko Kondow and Makoto Asashima

Int. J. Dev. Biol. (2004) 48: 327-332

Induction of tooth and eye by transplantation of activin A-treated, undifferentiated presumptive ectodermal Xenopus cells into the abdomen

Yasufumi Myoishi, Miho Furue, Yasuto Fukui, Tetsuji Okamoto and Makoto Asashima

Int. J. Dev. Biol. (2004) 48: 1105-1112

Developmental expression of Smad1-7 suggests critical function of TGF-beta/BMP signaling in regulating epithelial-mesenchymal interaction during tooth morphogenesis.

Xun Xu, Lesley Jeong, Jun Han, Yoshihiro Ito, Pablo Bringas and Yang Chai

Int. J. Dev. Biol. (2003) 47: 31-39

Analysis of the odontogenic and osteogenic potentials of dental pulp in vivo using a Col1a1-2.3-GFP transgene.

Alen Braut, Edward J Kollar and Mina Mina

Int. J. Dev. Biol. (2003) 47: 281-292

Diverse requirements for Notch signalling in mammals. Duncan B Sparrow, Melanie Clements, Sarah L Withington, Annabelle N Scott, Jiri Novotny, David Sillence, Kenro Kusumi, Rosa S P Beddington and Sally L Dunwoodie Int. J. Dev. Biol. (2002) 46: 365-374

Notch is required for outgrowth of the Xenopus tail bud. Caroline W Beck and Jonathan M W Slack Int. J. Dev. Biol. (2002) 46: 255-258

Basic mechanisms of cytodifferentiation and dentinogenesis during dental pulp repair. D Tziafas

Int. J. Dev. Biol. (1995) 39: 281-290

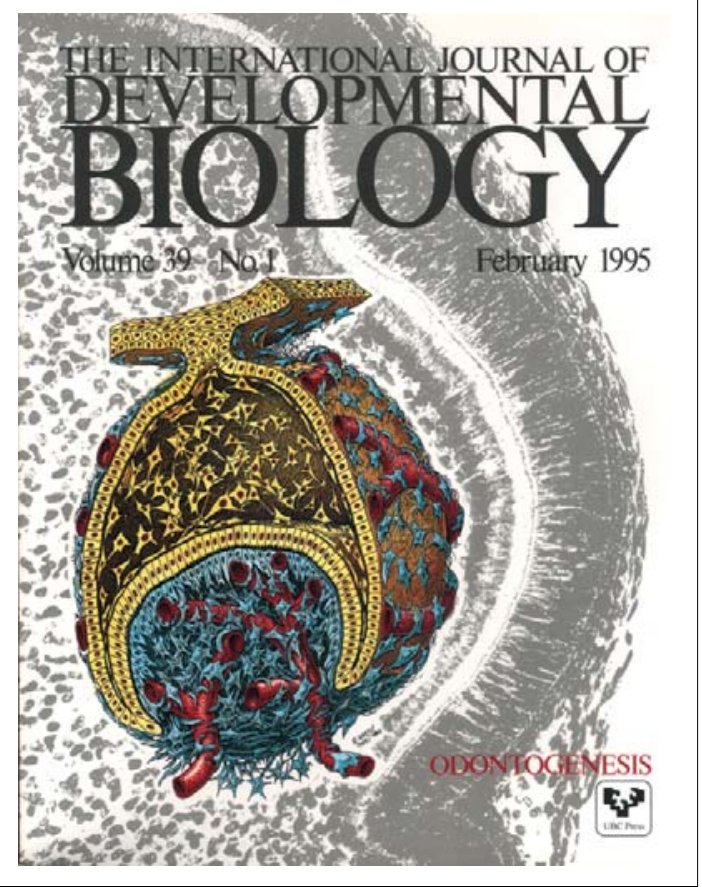

